\title{
Hegelian Master-Slave Dialectics: Lord Byron's Sardanapalus
}

\author{
Marziyeh Farivar ${ }^{1}$, Roohollah R. Sistani ${ }^{1} \&$ Masoumeh Mehni ${ }^{2}$ \\ ${ }^{1}$ School of Language studies and Linguistics, UKM, Malaysia \\ ${ }^{2}$ University Putra Malaysia, Malaysia \\ Correspondence: Marziyeh Farivar, School of Language Studies and Linguistics (PPBL), Faculty of Social \\ Science and Humanities (FSSK), University Kebangsaan Malaysia, Malaysia. Tel: 60-173-264-628. E-mail: \\ marziyeh.farivar1980@gmail.com
}

Received: December 12, 2012 Accepted: January 3, 2013 Online Published: January 17, 2013

doi:10.5539/ells.v3n1p16 URL: http://dx.doi.org/10.5539/ells.v3n1p16

\begin{abstract}
This paper intends to discuss Byron's "Sardanapalus" by focusing on the Hegelian master-slave dialectics. Written in 1821, "Sardanapalus" presents some trends about Lord Byron's creation of the Byronic Hero. The Byronic hero is emotional, dreamy, and impulsive. Sardanapalus, the Byronic hero, is the Assyrian King who possesses the complicated nature of both master and slave which is the focus of this article. There are encounters of masters and slaves that consciously and unconsciously take place in this dramatic verse. Sardanapalus' relationships to his mistress, his brother-in-law and the citizens involve a complex thesis and anti-thesis. Hegelian dialectics reflect the processes of recognition of consciousness through such thesis and anti-thesis. Bondage and lordship and dependency and independency are concepts that are within these processes. Hegel explains that the identity and role of the master and slave can be recognized when they are interacting. It means that the absolute situation in which one is alone cannot be appropriate for distinguishing. It attempts to explain how the master-slave patterns are recognized and defined, how the slaves and masters struggle internally and externally, and how they reach the recognition of the reality of their position and of self and how Sardanapalus as the Byronic hero acts. The focus of this article is on three master-slave patterns which are Sardanapalus-Myrrha, Sardanapalus-Salemenes and Sardanapalus-the citizens.
\end{abstract}

Keywords: Hegelian Master-Slave Dialectics, lordship, bondage, dependency, independency, recognition, self-consciousness, Sardanapalus

\section{Introduction}

According to Diodrus, Sardanapalus, "the thirtieth from Ninus, and the last King of the Assyrians, exceeded all his predecessors, in sloth and luxury..." (Booth, 1814). The description of Sardanapalus shows him as a character of illusions as he doesn't have any sense of reality in terms of governing the kingdom and observing the real life of both himself and people. He makes both men and women slaves work for him as he is the Emperor. He is confused about the meaning of peace, war and domination and being dominated as well. This means that he does not have the thoughtfulness and political intuition for running the kingdom and clearly he has forgotten how to protect it; "Sardanapalus hides himself because he knows that to be visible as a ruler demands being a soldier" (Bone, 2004). But he cannot envision himself as a soldier because his appearance is quite feminine.

The account of his life reveals about the last years of the Assyrian Empire. Lord Byron adjusted this story of several years into a single day which is one of the characteristics of classical tragedies (Hochman, 1984). The "Sardanapalus" is Byron's second tragedy written in 1821.

The works done by Lord Byron represents various trends and attitudes due to expressing different subjects about Romantic hero, orientalism, religion, women, history and nationalism. His Narrative and Dramatic verses are quite astonishing literature of his time and later times as according to Bone(2004), he is the only English writer that is most read after William Shakespeare. G. R Eliot (1924) in the article entitled "Byron and the Comic Spirit" admits Sardanapalus is similar to Don Juan (906). Don Juan is the Byronic hero whose attitude and trends are very similar to Lord Byron (Therslev, 1962). Don Juan as the Byronic hero is passionate, proud, arrogant and impulsive and daring (Therslev, 1962). He is the significant literary creation of Byron. He loves to be with women and he is not faithful. Eliot states that Don Juan and Sardanapalus possess same qualities in this way. 
Daniel P. Watkins adds that Sardanapalus goes beyond the historical perspective (Watkins, 1981). For he states that by writing this tragedy which is a historical one, Byron intended to combine the historical situation and a social incident together. Hence the dramatic verse tries to provide different situations and values for the individual so that one can feel the particular situation and its opposite simultaneously. The character of Sardanapalus is depicted as not having the desire to be in the society and moreover, he does not like to be physically involved in the matters. He also states Sardanapalus is the tragic hero who suffers from his thoughts-actions conflicts (808).

In addition, Behzad Ghaderi Sohi describes Sardanapalus as being "reluctant to play the predetermined role of a cruel king" (Ghaderi Sohi, 1997). He furthermore says that Sardanapalus is a comic character and he reveals this characteristic through situations such as when he speaks to his wife, when he looks into the mirror and when he talks about his destiny (155). Yet, Brewer in "The Shelly-Byron Conversation", writes that Byron's Sardanapalus gets the impressions from Shelly's Prometheus as the king is presented as "a would be pacifist" and "is punished for trying to become mankind's benefactor..." (Brewer, 1994).

Susan J. Wolfson on the other hand defines Sardanapalus as an "effeminate character" and gives the reference to William Hazlitt's explanation of effeminacy as the "prevalence of the sensibility over the will" (Wolfson, 1991). This notion is established from the start of the play as he was "effeminately dressed, his head crowned with flowers and his Robe negligently flowing..." (I,ii,1). The writer illuminates that "... not only does Byron associate it with a politics of evasion, he also embodies it in a hero cast as pampered, aristocratic, and effeminate all at once" (Wolfson, 1991). Poole, also, talks about "Sardanapalus' androgynous identity" (Poole, 1998). One of the situation which attracts the scholar's attention is the times and situations in which the King looks into the mirror. He emphasized that "whether homosexual or not, Sardanapalus is provocatively effeminate" (Poole, 1998). And the climax of his effeminate character is reported to be when he must attempt "to assume masculine roles" (Poole, 1998). The writer refers to Myrrha too via Sardanapalus' description that although he is her lover, he is able to recognize her brutality as well as politics (161). In this dissertation, the writer believes that the plot of the play deals with personal private values and the pressure of society (Poole, 1998).

The study done by Florence Toh Haw and Arbaayah Ali Termizi is approximately similar to the present study in terms of observing the master and slave relationship. The writers discuss this relationship in Shakespeare's Timon of Athens by applying the concept of Loyalty from Josiah Royce. It is stated that while the slave is a part of the master's household, the servant possesses self-will and the idea that "Shakespeare instructs his audience through loyal servants" (Toh Haw and Termizi, 2012).

This paper introduces Hegelian master-slave interpretation. The thesis and anti-thesis of this dialectics provides a profound philosophical point of view towards master-slave relationship (patterns) and various engagements of characters of Sardanapalus, Salemenes, Myrrha and the citizens in this dramatic verse. Investigating these patterns and applying the framework of Hegelian dialectics will be the argument of the present paper.

Hegel (1770-1831) is regarded as one of the most brilliant philosophers of the Western tradition. "The Phenomenology of Spirit" comprises of the very well-known interpretation of master-slave relation. In a particular chapter of this book, Hegel explains how the consciousness of the reader (a person) evolves from a lower level to a higher one and towards the recognition.

Before proceeding to the analysis of the dramatic verse of "Sardanapalus", it is important to establish the key aspects of Hegelian master-slave dialectics.

\section{Hegelian Master-Slave Dialectics}

Bondage-lordship and dependency-independency are the implications of the concept of master-slave. Hegel explains that the identity and role of the two of them can be recognized when they are interacting. It means that the absolute situation in which one is alone, cannot be appropriate for distinguishing. Thus "I gain a proper consciousness of myself only when my self-understanding is recognized and confirmed by others" (Houlgate, 2003).

Moreover, Hegel clarifies these two subjects in this way that master and slave exist as two contrasted form of consciousness; one of them is the dependent consciousness who lives for the other and one is independent who lives for him/herself (Leitch, 2001). It denotes that the slave is controlled by the master's power and authority and the slave's consciousness is dependent on what the master needs or commands.

Clearly this complex relationship involves a struggle of consciousness towards self-consciousness. This process requires recognition. These two human beings possess identities and social and individual entities; however the recognition of their identity means being self- conscious of the struggle and of the situation. Such ideas in 
master-slave patterns are quite complicated due to the fact that it is the master who exercises power over the slave but the master simultaneously needs the slave. Yet this relationship is not built at the first point of meeting and it takes time as both sides try to impose their own point of view. Margaret Kohn in her article "Frederick Douglass's Master-Slave Dialectic" refers to Hegel's idea that "each self-conscious tries to force the other to recognize his point of view while withholding reciprocal recognition from the other...(Kohn, 2005). And after that the idea of lordship and domination is established as the slave submits to the slave for saving his/her own life.

Hegel explicates that the "master" and "slave" are in fact "realities" as well as a "consciousnesses". And there is a mutual relationship between the master and the slave. It is inferred that they are interdependent and closely related to each other. Although the master proves his/her domination over the slave through the mentioned struggle but the slave comes to find out that the master depends on him/her. Thus the master feels uncertain about being consciously perceived as the master. In the first place, the master refers to himself as an independent person and thinks that the slave is not free and he is dependent. Hence the master is not able to understand the way the slave perceives him and the self. The result according to Hegel is one-sided unequal recognition.

On the other side of the dialectics, the anti-thesis is revealed at this point: the master is in complete freedom but he is dependant on the slave, but the slave is not dependant on the master; it means that the master becomes the slave of the slave.

There are other ideas in the master/slave relation: desire, labor, production and consummation and fear and death. These ideas clarify the master-slave relation and their consciousness evolution. The slave must work for his master's desire and consummation. The master desires to consume. Labor and work give the slave the consciousness of independency while the master is dependent on it. The slave may assume that the other self, the master, is unable to recognize the slave's true identity but the slave achieves his/her freedom by the job he/she does. Despite the orders and commands the slave takes, he/she perceives the self-consciously Death impacts negative understanding on the slave because the slave feels that after death he will be nothing. Such negative thought pushes him to do labor more seriously. Consequently, based on Hegel the slave moves towards freedom and consciousness of his being.

Hence, the verse drama of Sardanapalus employs this concept in so far as it can account for how the master and slave are identified, how these patterns are described in details and how based on Hegelian dialectic of master-slave relation, the thesis and antithesis are adjusted.

\section{Analysis}

\subsection{Sardanapalus, The King}

The story of the play is about Sardanapalus, an Eastern Assyrian Monarch. He tries to avoid wars as well as physical violence and to give people of his empire freedom. He is married and has two sons, yet he is in love with Myrrha, a Greek slave that represents the western thought.

From the beginning the physical role of Sardanapalus as a king is established by Salemenes by uttering the words such as "Lord", "Sovereign" and "great king of all. $(\mathrm{I}, \mathrm{i}, 1,4,36)$. Or the line that says: "...They come, the slaves, led by the monarch subject to his slaves" (I, i, 49-50).

These lines provide expectations about Sardanapalus in terms of being superior and having power as Hegel explains in the thesis that the master's consciousness forces the others to accept him as the man of power. It indicates that Sardanapalus' consciousness echoes itself through the others.

However, his character is shown as the one whose appearance is unlike a man or a king. The beginning of scene II of Act I proves this idea by describing him as "effeminately dressed, his head crowned with flowers, and his Robe negligently flowing; attended by a Train of Women and young Slaves" (Byron, 1823). It may mean that his physical reality and the consciousness are not adjusted together which indicates that he does not know himself as the man of power who should deal with the issues of the kingdom. He prefers to deal with the celebrations and happiness of life rather than paying attention to the facts of rebellions and conspiracy as he does not know what his subordinated people, officers and slaves do.

The physical situation says that he is a king and superior to others but the women-like aspects, so to speak, says that he is not. Clearly he does not consciously or unconsciously possess the authoritative gestures as a King due to his interest in the inconsiderate enjoyments which makes his lordship questionable. He refers to people of the country as "slaves" and he neither expects nor believes that they are capable of rioting against the master which traces him, based on Hegel's explanation, as being unconsciously inferior. When he is told that there is a riot in the city, he seems unaware of people and he says: "Have they not peace and plenty?" (I, ii, 198) and, 
"The restless slaves

Deserve that I should curse them with their wishes,

And lead them forth to glory." (I, ii, 219-221)

These lines reflect Sardanapalus' assumption that luxury is the only need of people. He does not understand that people's needs are more important than the luxuries and celebrations. And also:

"The ungrateful and ungracious slaves! They Murmur

Because I have not shed their blood, nor led them

To dry into the desert's dust by myriads,

Or whiten with their bones the banks of Ganges;

Nor decimated them with savage laws,

Nor sweated them to build up pyramids

Or Babylonian walls" (I, ii, 346-353).

He questioned his own justice through these lines. They indicate that he is aware of violence and injustice practiced in the past; yet he is unable to make distinctions. He is shocked and shows his resentment in these words:

"I have, by Baal! Done all I could to soothe them:

I made no wars, I added no new imposts,

I interfered not with their civic lives,

I let them pass their days as best might suit them,

Passing my own as suited me". (I, ii, 498-502)

The last two lines are the reference to Sardanapalus' mentality. He said that he has done suitable activity for people that were apt for him too; which highlights the King's infatuation with a luxurious life rather than with the real life and country matters which from the master-slave dialectics, he seems unconscious and unaware and tries to idealize the situation.

In addition, in act IV, he explains the situation to his wife in this way:

"These slaves, whom I have nurtured, pamper'd, fed,

And swoln with peace, and gorged with plenty, till

They reign themselves-all monarchs in their mansions

Now swarm forth in rebellion, and demand

His death, who made their lives a jubilee;

While the few upon whom I have no claim

Are faithful!..." (IV, i, 386-392).

Sardanapalus is unconsciously affected by the consciousness of his slaves who serve him. In fact he is serving the others by providing enjoyment and luxury. His point of view about people as well as his relationship with them is ambivalent. This ambivalent attitude is as a result of lack of proper recognition of self which has led to having the materialistic view that if people have food they must be satisfied. His consciousness and unconsciousness have opposite perceptions in the way that his consciousness does not have the true perception of self and therein from the Hegel's argument he unconsciously reveals slave-like trends.

For Sardanapalus “...war is no glory-conquest no/Renown” (IV, i, 635-636). Although war, restlessness, rage and brutality are not approved characteristics but Sardanapalus is confused about the meaning of these words. He is unaware that the glory of war may give him and his kingdom peace, freedom and comfort. And suddenly he comes to know that events which are running in his reign are absolutely against his expectation. He says to Salemenes:

"I am the lawful king, descended from

A race of kings who knew no predecessors.

What have I dine to thee, or to the people, 
That thou shouldst rail, or they rise up against me?" (I, ii, 19-20)

He has not reached the recognition of being a master whose role is ruling. He is a king because he inherited the kingdom and his son will be the Ruler after him. This hierarchy of power says that automatically the power is transferred through the particular generation. It implies that they (Kings) are conscious of becoming a king; yet they are incapable of any recognition of their identity as the King. Sardanapalus is not an exception; definitely he is the king but he is not conscious of the essence of a king and a ruler, so to speak, as a master. Sardanapalus believes that he is not a conqueror to deal with matters and in this way he thinks he is helping people of the nation as these lines reflect such way of thinking:

"The king, and son of Anacyndaraxes

In one day built Anchialus and Tarsus.

Eat, drink, and love; the rest's not worth a fillip" (I, ii, 374-377)

Or

"Obey the king-contribute to his treasure-

Recruit his Phalanx-spill your blood at bidding-

Fall down and worship, or get up and toil.”

...." I leave such things to conquerors, enough

For me, if I can make my subject feel

The weight of human misery less,...” (I, ii, 382-390)

However, he gradually recognizes that he is weak and broken and the following lines suggest he is confessing which according to Hegelian dialectics indicates that Sardanapalus gets consciousness through the reactions of slaves because his position as a master is defined when the others are slaves; hence when others do not accept him as a master, he won't recognize himself as a master as well:

"As I am heedless; and the slaves deserve to feel a master (I, ii, 536-537).

Sardanapalus seems to have an internal struggle within himself and in this struggle he is a thoughtful king who thinks about equality and freedom of the nation but according to Myrrha, this trend will not render the King glory. Even when Salemenes asks whether he is going to kill the rebels, Sardanapalus answers: "That's a hard question" (I, ii, 429).

Such expression reflects the Hegelian dialectics stating that even he is not able to decide upon the traitors who are his slaves. He is unconsciously connected with the slaves hence the decision about their trial involves him too. And his recognition of himself is going to be conscious and clear.

The physical war outside affects his consciousness and puts him within a questioning and deciding situation. He is not fearful in the beginning as he thinks every one depends on him; for example in act III, he starts his celebration while they are rioting outside, he is not anxious. But his slave Pania expresses his worries about the King while he has been wounded:

"Tis nothing- a more flesh wound.

I am Worn

More with my speed to warn my sovereign,

Than hurt in his defence." (III, i, 102-105)

Yet, by the end of the play he feels fear and he comes to understand the responsibility, dependency and self. After being conscious about the responsibility as a master, he commands about the safety of women (III, i, 168). In act IV, Sardanapalus reveals his concern about his family. He understands that he has not been a considerate husband for the family and he promises that:

“.... If e're we meet again, perhaps

I may be worthier of you-and, if not,

Remember that my faults, though not atoned for,

Are ended...." (IV, i, 484-487)

In addition to his wife and sons, he is worried about the safety of Myrrha. He intends to send her to her homeland which is not agreed about by her (IV, i, 599-601). 
He fights against the rebels in act V, holds the fight to cover his entourage's escaping and orders them to take the treasure and to free the slaves and lays the pyre. His self-immolation at the end of the play reveals his self-conscious recognition.

Sardanapalus is a master according to the tradition of his ancestors. He feels free to do everything he desires. Slaves respect, recognize and serve him. Thus in his limited palace, he believes he is ruling without a question. He does not have practical social contacts for checking upon values and self-definition as he lives in luxury and among women and pleasures. Working and laboring are not his concerns and interests and he is a consumer. He is self-conscious about the independency as he does not care about matters which according to Hegel mean the lack of conscious recognition. His recognition about his position tells him that he stands as a master. While the Monarch recognizes himself at the peak, the situation changes: there is a rebel inside and outside the palace. Sardanapalus considered himself as the Great master ever since, but is frightened. He feels consciously dependant which makes him the Slave. In fact he is double the slave: the slave of slaves. Afterwards, when he self-consciously understands that every thing about companionship and glory is going to end, he feels the unexpected loneliness:

“... I would fall

Alone-I seek no partners but in pleasure.” (IV, i, 607)

Just before conflagration, he hears from a messenger that one of the rebels has been crowned as a king. Such bitter truth proves that he is no longer a master as well.

The next sections of the present article argue the connection of Sardanapalus to Myrrha, Salemenes and the citizens while the key terms of Hegelian master-slave dialectics are the points of reference.

\subsection{Sardanapalus and Myrrha}

Myrrha, the lover, the source of inspiration and the slave, admits her inferiority to the king constantly throughout the play. She always obeys the king. Sardanapalus-Myrrha is the important master-slave relationship mainly because of gender consideration. Myrrha is a woman from Greece. In this work, she is described as a thoughtful person. Byron could not ignore the essentialism of the West and being as a slave does not mean that she consciously embraces it. Myrrha's idea and feelings about her homeland emphasized the superiority of the West. She does not approve when another person talks about Greece. The following lines echo how Byron has made connection between the West and Myrrha's fearlessness:

"Fear!-I'm a Greek, and how should I fear

Death?" (I, ii, 650-651)

Sardanapalus is extremely attached to her and admits that he would resign as a King for her:

"Wish that I could lay down the dull tiaras,

And share a cottage on the Caucasus

With thee, and wear no crowns but those of flowers". (I, ii, 609-611)

She is a precious one:

"... i had rather lose

An empire than thy presence" (I, ii, 127-128)

And moreover the king says that he loves her

“...far more

Than either the brief life or the wide realm" (I, ii, 656)

All the examples presenting Sardanapalus' affection for Myrrha reveal that the king is emotionally dependent. This denotes that the king is unconsciously aware of her wisdom, authority and independency. Furthermore, the king admits that she is a courageous person. (IV, i, 626).

She is self-conscious of her situation. She is a wise Greek slave whose words move the monarch towards recognition. She tells the king that:

"Alas! My lord, with common men

There needs too oft the show of war to keep

The substance of sweet peace; and for a king, 
'Tis sometimes better to be fear'd than loved." (I, ii, 712-715)

Myrrha informs Sardanapalus that people and slave must be kept under the law. She is not afraid of the situation and tries persistently to keep him aware. She believes in herself She is a doer as well as a confident slave woman:

“...I love him; the slave loves

Her master, and would free him from his vices.

If not, I have a means of freedom still,

And if I cannot teach him how to reign,

My show him how along a king can leave

His throne" (I, ii, 875-880)

In another part of the play, in act V, when Pania is surprised that Myrrha wants to light the fire, he says:

"I should shame to leave my sovereign

With a single female to partake

His death." (V, i, 505-507)

These lines depict the braveness and fearfulness of the woman as a slave. She feels that her love to the king has set her free and she has forgotten about being a slave. She is consciously faithful to Sardanapalus as her lover and when she is asked to go through a secret passage and to stay there till the arrival of the king, she refuses:

N! I'll die here!-Away, and tell your King

I love him to the last." (III, i, 338-340)

However when Sardanapalus asks whether she knows him still as her king, Myrrha replies:

"I would not have him less than what he

Should be" (III, i, 552-553)

Myrrha shows her strength and loyalty to the king in so far as when Sardanapalus and Salemenes are talking, in response to Salemenes:

"That slave deserves her freedom" (IV, i, 234)

Sardanapalus replies:

"That slave deserves to share a throne." (IV, i, 236)

Myrrha is the symbol of the West and Sardanapalus signifies the East. The West has the hegemonic power over the East. The character of Myrrha strongly reveals this idea. She knows how to make the king move from a two dimensional shape into a three dimensional one which means that she speaks to him convincingly which makes him think and act. She loves the master, obeys his orders and commands and mounts the pyre and accompanies Sardanapalus for partaking in the conflagration. She voluntarily sacrifices herself because of her awareness, acceptance and self-consciousness of her reality. Myrrha is a slave in the palace but the men of the king say that:

"We honor her of all things next to thee." (III, i, 82)

In relation to this, Myrrha is the Hegelian master as she is honored, brave and thoughtful and she has achieved her recognition of self

\subsection{Sardanapalus and Salemenes}

In addition, there are other characters that are initially regarded as slaves: those who perform their duty to King Sardanapalus. One is Salemenes, his brother-in-law, who plays the role of being a trustable and reliable friend, brother and consultant for the King.

He describes himself as the king's "most faithful vessal..." (I, i, 91). Although he knows that Sardanapalus betrays his sister by loving Myrrha, but he is loyal to the King and confirms his position as a slave. He has recognized his own self; hence he is self-consciously self-conceptualized, Salemenes tries to do as a slave. He knows that he is defined by the meaning that the King allocates to him. Salemenes is the one that pictures Sardanapalus very well from the beginning of the story that the King possesses a feminine appearance and he does not show dignity and qualification of a King. Salemenes believes that “.... He must be roused..." (I, i, 29).

He wants to make Sardanapalus self-conscious thus he says to him: 
I only echo thee the voice of empires,

Which he who long neglects not long will govern (I, ii, 344-345)

It states that the master's voice has been vanished and as a result the slaves do not think of him as a Master. Salemenes is a rational person, he is aware of his own situation. The degree of his recognition of self allows him to make decisions freely and logically. When Sardanapalus complains about the current attitude of people and slaves toward him, Salemenes does not conceal the truth and says:

Thou stopp'st

Short of the duties of a king; and therefore

They say thou art unfit to be a monarch (I, ii, 503-505)

He forces Sardanapalus to understand the shortcomings, that he was not conscious of his identity and responsibilities:

"Keep thou awake that energy

Which sleeps at times, but is not dead within thee,

And thou may'st yet be glorious in thy reign,

And powerful in thy realm." (I, ii, 528-532).

\subsection{Sardanapalus and Citizens}

Sardanapalus- Citizens is the pattern that carries the thesis and anti-thesis as well. It may reflect the ideology of romanticism that emphasizes on the right of individuals stating that individuals are capable of expressing themselves freely. Sardanapalus is the king of his people and the struggle and interactions between the citizens and him depict Sardanapalus as a dependent master whose lordship is no longer recognized as legitimate. He was expected to be a King as there has been the hierarchy of power. He repeatedly calls people as his slaves. He is the master but in fact, he is not accepted as one. People do not perceive him as a King which implies the refutation of his lordship over them. They expect the King to act as a powerful person and to make bondage through power and service but Sardanapalus is not such which based on Hegelian dialectics is due to his unconscious quality of being dependant on people and his lack of self-recognition. Citizens are rioting and he cannot understand the reason what their intentions are, he says:

"Who should rebel? Or why? What cause?

Pretext?" (I, ii, 315-316)

People rebel against him and Salemenes discusses with Sardanapalus about the reasons of this rebellious actions in the following lines:

“... The despotism of vice-

The weakness and the wickedness of luxury-

The negligence-the apathy-the evils

Of sensual sloth-produce ten thousand tyrants

Whose delegated cruelty surpasses

The worst acts of one energetic master,...” (I, i, 145-150)

Sardanapalus- Citizens signifies the pattern of a leader-society. The attitude that is shown by Byron is similar to what happened in France in the $18^{\text {th }}$ century. The revolution of people led to the break down of the King and the royal family. Romanticism has its origin from that French revolution and Byron has extended his romantic ideology into this work as Sardanapalus is portrayed as the Romantic hero. He does not care about people in an authoritative way. On the other hand, Sardanapalus does not know what people's needs are exactly. According to Salemenes, he is not able to hear "the echoes of the nation's voice" (I, ii, 181). The King refers to the people as the heritage of his father while people do not accept him as their King and he comes to know he is nothing in "their eyes" (I, ii, 194).

Salemenes acknowledges it to Sardanapalus that he has wasted all the traits a King must have possessed. The King has preferred to spend the time in celebrations and revel and he has lost the ruling attitude. According to him, sometimes the people need to be suppressed rather than to be left in freedom:

"That they will need he sword more than your scepter." (I, ii, 248) 
Salemenes informs the King about his shortcomings that make him distant from the liable Ruler. According to these lines:

“Thou stopp'st

Short of the duties of a King; and therefore

They say thou art unfit to be a monarch.” (I, ii, 503-505)

Sardanapalus is a king who is not conscious of his reality; he does not perform what is expected from a ruler which makes him the slave to the others.

\section{Conclusion}

Slave-master pattern embodies the struggle for recognition according to Hegel. It concerns fear, labor and work, consuming and producing. It deals with self-understanding and recognition. The dramatic verse of Sardanapalus which is known as one of the best tragedies of Lord Byron possesses this pattern that deserves being noticed from two points of views of thesis and anti-thesis by examining through two essential key terms of lordship/bondage and dependency/independency. The thesis reveals that Sardanapalus is the King. He is conscious about this reality as a physical Ruler. He does not fear and hence he feels independent. Although he is the superior one but he unconsciously hides from the serious events of the kingdom. He is from the East which presents him being attached to the exotic patterns. On the other side there is a Western lover, Myrrha who is the slave as well as a loyal, brave, considerate and thoughtful individual which according to Hegelian master-slave dialectics acknowledges her lordship over the master. It means although she is a woman in the society in which men's dominate and superiority has been established, she proves to be superior and independent. That is how the thesis turns into the anti-thesis: Sardanapalus is a dependant man and he is not free but Myrrha, unlike her physical situation, is consciously free. Sardanapalus is dominated by Myrrha, in other words, the East is controlled by West. Therefore based on Hegel master-slave dialectics, it can be inferred that the King becomes self-conscious of his reality of being dependant and this self-understanding reveals him being a slave and thus he as the Byronic hero becomes the Hegelian slave.

\section{Reference}

B. Leitch, Vincent. (Ed). (2001). The Norton anthology of theory and criticism. Hegel's Master-slave Dialectics. New York: Norton.

Bone, D. (2004). The Cambridge Companion to Byron. UK: Cambridge University Press. http://dx.doi.org/10.1017/CCOL0521781469

Booth, G. (1814). The historical Library of Diodorus the Sicilian: In fifteen book to which are added the Fragments of Diodorus, and those published by H. Valesius, I. Rhodomannus, and F. Ursinus (Vol. I). London: W.M'Dowall.

Elliot, G. R. (1924). Byron and the comic spirit. PMLA, 39(4), 897-909. http://dx.doi.org/10.2307/457253

Florence Toh Haw Ching, \& Arbaayah Ali Termizi. (2012). Roycean Loyalty in Willian Shakespeare's Timon of Athens. Gema Online ${ }^{\mathrm{TM}}$ Journal, 12(2), 343-358.

Ghaderi sohi, Behzad. (1997). Theatre of the mind: A comparative study of British romantic dramatists with 5 contemporary British dramatists. PhD Thesis, University of Essex.

Hegel, GWF. (1967). The Phenomenology of spirit (Translated by J. B. Baillie). New York: Harper Torch Book.

Hochman, S. (1984). McGraw-Hill Encyclopedia of world drama: An international reference. USA: VNRAG.

Houlgate, S. (2003). G.W.F. Hegel: The phenomenology of spirit (Chapter 1). The Blackwell guide to continental Philosophy: Wiley Online Library.

Kohn, M. Frederick Douglass's master-slave dialectic. The Journal of Politics, 2005, 67(2), 497-514. Published by Cambridge University Press on behalf of the Southern Political Science Association Stable.

Lord Byron. (1823). Sardanapalus: A Tragedy. London: John Murray, Albemarle-Street.

P. Watkin, Daniel. (1981). Violence, class consciousness and ideology in Byron's history plays. ELH, 48(4), 799-816. http://dx.doi.org/10.2307/2872962

Poole, Gabriel. (1998). Byron's Heroes and The Byronic Hero. Ph.D Dissertation. Department of English. Notre Dame, Indiana.

Therslev, P. L. (1962). The Byronic hero: Types and prototypes. US: the University of Minnesota. 